\title{
KEUNGGULAN KLON KARET IRR 220 dan IRR 230
}

\author{
The Superiority of IRR 220 and IRR 230 Rubber Clone
}

\author{
Sekar Woelan ${ }^{1}$, Rasidin Azwar ${ }^{2}$, Aidi-Daslin², Irwan Suhendry ${ }^{2}$, Mudji Lasminingsih", \\ Sayurandi ${ }^{2}$, dan Syarifah A. Pasaribu ${ }^{2}$ \\ ${ }^{1}$ Pusat Penelitian Karet. J1. Salak No.1 Bogor 16151. Indonesia \\ ${ }^{2}$ Balai Penelitian Sungei Putih. Sungei Putih - Galang, Sumatera Utara, \\ P.O. Box 1415 Medan 20001 \\ ${ }^{3}$ Balai Penelitian Sembawa. J1. Raya Palembang-P. Balai, Km29, \\ Sumatera Selatan, P.O. Box 1127 Palembang 30001 \\ Email:sekaryudi@yahoo.com
}

Diterima 15 Maret 2016 / Direvisi 14 November 2016 / Disetujui 5 Desember 2016

\begin{abstract}
Abstrak
Klon IRR 220 dan IRR 230 merupakan hasil persilangan tahun 1985 s.d 1990. Pengujian dilakukan di beberapa agroekosistem. Tujuannya untuk mengevaluasi penampilannya Pertumbuhan jagur dan disadap umur 4 tahun, resisten terhadap penyakit Corynespora, Colletotrichum dan Kering Alur Sadap (KAS). Potensi produksi lateks IRR 220 yaitu 115\% diatas PB 260 , respon terhadap stimulan sedang dan dikelompokkan pada klon metabolisme tinggi. IRR 230 potensi produksi sama dengan $\mathrm{PB}$ 260 , respon stimulan tinggi $\pm 122 \%$ dan dikelompokkan pada klon metabolisme sedang. Potensi produksi kayu IRR 220 sebesar $0,61 \mathrm{~m}^{3} / \mathrm{ph}$ dan total volume kayu $0,89 \mathrm{~m}^{3} / \mathrm{ph}$ dan IRR 230 yaitu $0,76 \mathrm{~m}^{3} / \mathrm{ph}$ dengan total volume kayu $1,17 \mathrm{~m}^{3} / \mathrm{ph}$ umur 20 tahun. Tebal kulit IRR 220 cukup tebal pada kulit murni maupun kulit pulihan, jumlah pembuluh lateks di kulit murni lebih banyak dibanding PB 260. Tebal kulit murni dan jumlah pembuluh lateks IRR 230 sama dengan klon PB 260. Keunggulan IRR 220 dan IRR 230 sebagai klon lateks-kayu dan adaptabilitasnya pada daerah dengan curah hujan tinggi (basah) sampai rendah (kering). Klon tersebut telah mendapatkan Hak Perlindungan Varietas
\end{abstract}

Tanaman dari Pusat Perlindungan Varietas Tanaman Dan Perizinan Pertanian dan SK Pelepasan Varietas Unggul dari Menteri Pertanian, masing-masing Sertifikat Nomor : $00302 / \mathrm{PPVT} / \mathrm{T} / 2014$; SK Nomor: 77/Kpts/KB.020/1/2016 (IRR 220) dan Sertifikat Nomor 00303/PPVT/T/2014; SK Nomor : 74/Kpts/KB.020/1/2016 (IRR 230) No. 00302 / PPVT / T / 2014.

Kata kunci: Hevea brasiliensis, benih bina, IRR 220, IRR 230

\section{Abstract}

IRR 220 and IRR 230 clones were crossed result in 1985 s.d 1990 years. Clone tested had been carried out at different agroecosystem. The objective of study was observed of performance. Vigourus clones and resistant to Corynespora, Colletotrichum, and tapping panel draynes disease. The yield of IRR 220 was $115 \%$ above $P B 260$ and response to stimulants moderate and high metabolism. IRR 230 have yield equal with $P B 260$, respons stimulant $\pm 122 \%$ and moderate metabolism. Yield of rubber wood IRR 220 was $0.61 \mathrm{~m}^{3} /$ tree and a total rubber wood 0.89 $\mathrm{m}^{3} /$ tree and IRR 230 was $0.76 \mathrm{~m}^{3} /$ tree with a total rubber wood $1.17 \mathrm{~m}^{3} /$ tree at 20 years. IRR 220 have the virgin bark and renewable bark more thickness than PB 260. The number of latex vessels and virgin 
bark thickness of IRR 230 was the same than $P B$ 260. The superiority of IRR 220 and IRR $230 \mathrm{had}$ as latex - timber clones and could be adaptability in high rainfall (wet) to low (dry) areas. The clone had been gained Intelectual Property Right of Plant Variety Protection from Right Center of Plant Variety Protection and Agriculture Licensing and Release of Varieties Document from the Ministry of Agriculture respectively, Certificates No.00302 / PPVT / T / 2014; Decree No. 77 / Kpts / KB.020 / 1/2016 (IRR 220) and Certificate No. 00303 / PPVT / T / 2014; Decree No. 74 / Kpts / KB.020 / 1/2016(IRR 230).

Key word: Hevea brasiliensis, recommendation seed, IRR 220, IRR 230

\section{Pendahuluan}

Peningkatan produktivitas tanaman akan berhasil apabila digunakan klon-klon unggul baru pada setiap kali penanaman ulang atau baru. Klon-klon unggul baru yang telah direkomendasikan merupakan hasil seleksi baik dari dalam maupun luar negeri. Saat ini di dalam negeri sedang berlangsung seleksi klon Generasi ke IV (G-IV) di Pusat Penelitian Karet, yang dilakukan oleh Balai Penelitian Sungei Putih (Azwar et al., 1998; Woelan et al., 2001). Klon-hasil seleksi diberi nama dengan klon seri IRR (Indonesian Rubber Research).

Kemajuan pemuliaan tanaman karet selama tiga siklus seleksi telah banyak dirasakan manfaatnya bagi peningkatan produktivitas baik secara nasional maupun dari masing-masing pekebun. Dengan penggunaan klon unggul rata-rata peningkatan produktivitas dari awalnya $400-500 \mathrm{~kg} / \mathrm{ha} / \mathrm{th}$ (bahan tanam berupa seedling) menjadi 1400 $2000 \mathrm{~kg} / \mathrm{ha} /$ th (Aidi Daslin et al., 1995; Azwar dan Aidi-Daslin, 1993). Sejak tahun 1995, pengelompokan klon dikategorikan sebagai penghasil lateks, penghasil lateks-kayu, dan penghasil kayu. Potensi hasil lateks klon-klon terbaru diharapkan mencapai lebih dari 40 ton/ha dalam 20 tahun masa eksploitasi dengan potensi kayu yang dihasilkan mencapai lebih dari $300 \mathrm{~m}^{3} / \mathrm{ha}$ /siklus. Kayu karet memenuhi persyaratan mutu kayu olahan yang dapat mensubtitusi kebutuhan kayu dari hutan alam (Chin and Koo, 1977), karena dapat memenuhi persyaratan mutu kayu olahan baik dilihat dari sifat fisik, mekanis, dan kimiawinya. Limbah kayu karet dapat dibuat papan serat atau pulp, dan arang. Arang kayu karet termasuk kedalam arang kayu komersial dan sesuai untuk diolah menjadi arang aktif(Permadi, 2010).

Berdasarkan ketentuan UU Nomor 12 Tahun 1992 dan Peraturan Pemerintah yang berlaku tentang perbenihan (Pusat Penelitian Karet, 1995), semua varietas atau klon yang akan dikembangkan harus dilepas resmi oleh Menteri Pertanian.

Berkenaan dengan UU tersebut di atas, terjadi adanya perubahan pengelompokan klon anjuran.

- Klon anjuran komersial adalah klon unggul yang dianjurkan untuk pengembangan komersial yang menurut Undang-Undang No. 12 Tahun 1992 disebut sebagai Benih Bina dan pelepasannya dilakukan secara resmi melalui Surat Keputusan Menteri.

- Klon harapan adalah klon-klon yang pada pengujian pendahuluan terbukti memiliki sifat keunggulan lebih baik dari klon anjuran komersial, namun belum teruji secara luas. Klon harapan dianjurkan masuk pengembangan skala terbatas oleh pekebun melalui kerjasama pengembangan dengan Pusat Penelitian.

Dalam rangka mengimplementasikan Undang-Undang No. 12 Tahun 1992, maka Pusat Penelitian Karet akan melepas klon unggul baru hasil seleksi dalam negeri, yaitu klon IRR 220 dan IRR 230. Klon IRR 220 dan IRR 230 berasal dari kelompok klon yang terseleksi dari pengujian pendahuluan (Suhendry et al., 1998), plot promosi klon IRR seri 100 dan 200 (Woelan dan Azwar, 1992; Woelan et al., 2005; Woelan et al., 2009). Klon IRR seri 100 dan 200 merupakan klon unggul harapan hasil seleksi dari Pusat Penelitian Karet di Sungei Putih yang sejak Juni tahun 2003 berubah menjadi Balai Penelitian Sungei Putih. Persilangan dilakukan pada tahun 1985 s.d 1990 pada pohon yang dipendekkan di Kebun Percobaan Sungei Putih. Kedua klon tersebut diatas berasal dari sebanyak 37.525 persilangan, dengan tanaman F1 yang dihasilkan sejumlah 657 genotipe. 
Seleksi dilakukan pada tanaman F1 hasil persilangan yang ditanam di Seedling Evaluation Trial (SET) dengan jarak tanam yang digunakan adalah $1 \mathrm{~m} \times 1 \mathrm{~m}$. Seleksi individu dilakukan berdasarkan potensi produksi dan sifat-sifat pertumbuhan serta ketahanan terhadap penyakit. Potensi produksi diamati dengan menggunakan metode sadap HMM (Hamerker Morris Man) selama 6 bulan, sistem sadap yang digunakan $1 / 2 \mathrm{~S} \mathrm{~d} / 3$ pada ketinggian $50 \mathrm{~cm}$. Dari hasil seleksi $1 \%$ terbaik diketemukan sebanyak 21 genotipe terbaik. Genotipe-genotipe ini kemudian diperbanyak secara vegetatif (okulasi) dan digunakan sebagai materi seleksi di pengujian plot promosi dengan klon pembanding yang digunakan yaitu PB 260 . Sebanyak $10 \%$ terbaik masuk ke dalam uji pendahuluan. Tahun 1995, pertama kali dilakukan pengujian di Kebun Percobaan Balai Penelitian Sungei Putih-Sumatera Utara, dan saat ini telah memasuki masa TM (Tanaman Menghasilkan). Pengujian di Kebun Balai Penelitian Sembawa-Sumatera Selatan pada tahun 1994, di perkebunan Socfindo yaitu kebun Aek Paminke-Sumatera Utara dilakukan pada tahun 2005. Selanjutnya pada tahun 2010 pengujian dilakukan di perkebunan rakyat Aek TarumSumatera Utara.

Tujuan pemuliaan ini adalah mendapatkan klon IRR (Indonesian Rubber Research) seri 200 yang mempunyai karakter dengan potensi produksi lateks $\geq 2500 \mathrm{~kg} / \mathrm{ha} / \mathrm{th}$, produksi kayu $\geq 300 \mathrm{~m}^{3} /$ ha pertumbuhan jagur, dan sifat-sifat sekunder lainnya seperti ketahanan terhadap penyakit daun (Corynospora, Colletotrichum) lebih baik, Kering Alur Sadap (KAS) dan respon terhadap stimulan.

Makalah ini akan menyajikan dan membahas data-data pertumbuhan, produksi, ketahanan penyakit, sifat lateks, karet dan kayu, serta keunggulan lain yang dimiliki oleh IRR 220 dan IRR 230 yang terbukti unggul pada plot pengujian. Pengujian pengembangan klon tersebut mulai dibangun di perkebunan rakyat dan perkebunan besar.

\section{Potensi Produksi}

Potensi produksi klon IRR 220 dan klon pembanding PB 260 yang tidak distimulan di Kebun Percobaan Sungei Putih, di Kebun Sembawa, dan Aek Paminke telah disajikan pada Tabel 1. Rata-rata potensi produksi tanpa stimulan klon IRR 220 lebih tinggi dibanding klon PB 260 sebesar 115\% (Woelan et al., 2001; Woelan et al., 2005; Woelan et al., 2006). Secara statistik menunjukkan terjadinya perbedaan yang nyata antara hasil lateks IRR 220 dengan PB 260. Berdasarkan pengelompokan yang dilakukan oleh Azwar dan Suhendry (1998), klon IRR 220 termasuk tipe klon penghasil cepat dan pertumbuhannya relatif jagur.

Peningkatan produksi dengan penggunaan stimulan $2,5 \%$ selama 9 tahun penyadapan lebih rendah dibanding tanpa stimulan sehingga dapat disimpulkan bahwa klon IRR 220 kurang respon terhadap pemberian stimulan. Apabila dilihat pola potensi produksi klon IRR 220 rata-rata g/p/s dari tahun ke tahun relatif stabil, baik yang distimulan maupun yang tidak distimulan. Dari Tabel 1 juga dapat dilihat hasil pengamatan pada bidang sadap, menunjukkan klon IRR 220 cukup bersih dari BB (Brown Bast), KL (Kanker Lum), dan BN (Bark Nekrosis). Disini dapat dikatakan bahwa klon IRR 220 cukup tahan (resisten) terhadap penyakit bidang sadap.

Potensi produksi klon IRR 230 dan klon pembanding PB 260 di Kebun Percobaan Sungei Putih, di Kebun Sembawa dan Aek Paminke telah disajikan pada Tabel 2. Hasil analisis statistik menunjukkan tidak adanya perbedaan yang nyata antara hasil lateks IRR 230 dengan PB 260 seperti yang disajikan pada Tabel 2. Berdasarkan pengelompokan yang dilakukan oleh Azwar dan Suhendry (1998), klon IRR 230 termasuk tipe klon penghasil cepat dan pertumbuhannya jagur atau penghasil lateks-kayu. Klon IRR 230 sangat respon terhadap pemberian stimulan 2,5\% sebesar $122 \%$. 
Tabel 1. Potensi produksi g/p/s (kg/ha/th) klon IRR 220 tanpa stimulan dengan sistim sadap $(1 / 2 \mathrm{~S} \mathrm{~d} / 3)$

\begin{tabular}{|c|c|c|c|c|c|c|c|c|c|c|c|c|c|}
\hline \multirow[t]{2}{*}{ Klon } & \multicolumn{11}{|c|}{ Produksi g/p/s (kg/ha/th) tanpa stimulan dan kumulatif tahun ke } & \multicolumn{2}{|c|}{ Rata-rata } \\
\hline & 2 & 3 & 4 & 5 & 6 & 7 & 8 & 9 & 10 & 11 & 12 & $(2-4)$ & $(2-8)$ \\
\hline \multicolumn{14}{|c|}{ Balai Penelitian Sungei Putih - Sumut } \\
\hline IRR & 43,0 & 36,6 & 43,0 & 51,2 & 60,6 & 64,4 & 86,3 & & & & & 43,5 & 57,0 \\
\hline 220 & $(1.944)$ & $(1.654)$ & $(1.944)$ & $(2.314)$ & $(2.739)$ & $(2.911)$ & $(3.901)$ & & & & & $(1.966)$ & $(2.576)$ \\
\hline $\mathrm{PB}$ & 37,7 & 32,2 & 36,9 & 42,2 & 68,3 & 57,5 & 67,4 & & & & & 37,3 & 50,8 \\
\hline 260 & $(1.704)$ & $(1.455)$ & $(1.668)$ & $(1.907)$ & $(3.087)$ & $(2.599)$ & $(3.046)$ & & & & & $(1.672)$ & $(2.296)$ \\
\hline \multicolumn{14}{|c|}{ Balai Penelitian Sembawa - Sumsel } \\
\hline IRR & 63,4 & 54,5 & 51,2 & & & & & & & & & 55,8 & \\
\hline 220 & $(2.866)$ & $(2.463)$ & $(2.314)$ & & & & & & & & & $(2.522)$ & \\
\hline $\mathrm{PB}$ & 29,7 & 39,0 & 34,1 & & & & & & & & & 35,3 & \\
\hline 260 & $(1.342)$ & $(1.763)$ & $(1.541)$ & & & & & & & & & $(1.596)$ & \\
\hline \multicolumn{14}{|c|}{ AekPaminke,Socfindo - Sumut } \\
\hline IRR & 46,0 & 56,7 & 65,2 & & & & & & & & & 54,7 & \\
\hline 220 & $(2.079)$ & $(2.563)$ & $(2.947)$ & & & & & & & & & $(2.441)$ & \\
\hline $\mathrm{PB}$ & 50,6 & 51,8 & 47,1 & & & & & & & & & 49,8 & \\
\hline 260 & $(2.287)$ & $(2.341)$ & $(2.129)$ & & & & & & & & & $(2.251)$ & \\
\hline
\end{tabular}

Sumber: Woelan et al.,(2005, 2009); Lasminingsih, et al., (2009).

Keterangan :- Sistem sadap 1/2S d/3 (113 hari, 400 pohon)

Tabel 2. Potensi produksi g/p/s (kg/ha/th) klon IRR 230 tanpa stimulan (1/2 S d/3)

\begin{tabular}{|c|c|c|c|c|c|c|c|c|c|c|c|c|c|c|}
\hline \multirow[t]{2}{*}{ Klon } & \multicolumn{13}{|c|}{ Produksi $\mathrm{g} / \mathrm{p} / \mathrm{s}(\mathrm{kg} / \mathrm{ha} / \mathrm{th})$ tanpa stimulan dan kumulatif tahun ke } & \multirow[t]{2}{*}{ Rata-rata } \\
\hline & 1 & 2 & 3 & 4 & 5 & 6 & 7 & 8 & 9 & 10 & 11 & 12 & 13 & \\
\hline \multicolumn{15}{|c|}{ Balai Penelitian Sungei Putih-Sumut } \\
\hline IRR 230 & $\begin{array}{c}38,2 \\
(1.727)\end{array}$ & $\begin{array}{c}40,9 \\
(1.849)\end{array}$ & $\begin{array}{c}42,1 \\
(1.903)\end{array}$ & $\begin{array}{c}56,8 \\
(2.567)\end{array}$ & $\begin{array}{c}42,3 \\
(1.912)\end{array}$ & $\begin{array}{c}50,2 \\
(2.269)\end{array}$ & $\begin{array}{c}40,5 \\
(1831)\end{array}$ & $\begin{array}{c}39,1 \\
(1.767)\end{array}$ & $\begin{array}{c}46,3 \\
(2.093)\end{array}$ & $\begin{array}{c}48 \\
(2.170)\end{array}$ & $\begin{array}{c}64 \\
(2.893)\end{array}$ & $\begin{array}{c}49,2 \\
(2.224)\end{array}$ & $\begin{array}{c}57,4 \\
(2.594)\end{array}$ & $\begin{array}{c}47,3 \\
(2.138)\end{array}$ \\
\hline PB 260 & $\begin{array}{c}42,4 \\
(1.916)\end{array}$ & $\begin{array}{c}31,9 \\
(1.442)\end{array}$ & $\begin{array}{c}36,4 \\
(1.645)\end{array}$ & $\begin{array}{c}36,5 \\
(1.650)\end{array}$ & $\begin{array}{c}53,09 \\
(2.400)\end{array}$ & $\begin{array}{c}67,63 \\
(3.057)\end{array}$ & $\begin{array}{c}86,3 \\
(3.901)\end{array}$ & $\begin{array}{c}47,2 \\
(2.133)\end{array}$ & $\begin{array}{c}33,8 \\
(1.528)\end{array}$ & $\begin{array}{c}25,8 \\
(1.166)\end{array}$ & $\begin{array}{c}20,5 \\
(927)\end{array}$ & $\begin{array}{c}42,4 \\
(1.916)\end{array}$ & & $\begin{array}{c}43,7 \\
(1.979)\end{array}$ \\
\hline \multicolumn{15}{|c|}{ Balai Penelitian Sembawa-Sumsel } \\
\hline IRR 230 & $\begin{array}{c}40,5 \\
(1.831)\end{array}$ & $\begin{array}{c}37,6 \\
(1.700)\end{array}$ & $\begin{array}{c}25,2 \\
(1.139)\end{array}$ & $\begin{array}{c}33,3 \\
(1.505)\end{array}$ & $\begin{array}{c}22 \\
(994)\end{array}$ & $\begin{array}{c}33,9 \\
(1.532)\end{array}$ & & & & & & & & $\begin{array}{c}44,0 \\
(1.988)\end{array}$ \\
\hline PB 260 & $\begin{array}{c}35,5 \\
(1.605)\end{array}$ & $\begin{array}{c}29,7 \\
(1.342)\end{array}$ & $\begin{array}{c}39,0 \\
(1.763)\end{array}$ & $\begin{array}{c}34,1 \\
(3.853)\end{array}$ & $\begin{array}{c}38,2 \\
(1.727)\end{array}$ & $\begin{array}{c}34,8 \\
(1.573)\end{array}$ & & & & & & & & $\begin{array}{c}44,3 \\
(2.001)\end{array}$ \\
\hline \multicolumn{15}{|c|}{ Aek Paminke,Socfindo-Sumut } \\
\hline IRR 230 & $\begin{array}{c}30,0 \\
(1.356)\end{array}$ & $\begin{array}{c}43,0 \\
(1.944)\end{array}$ & $\begin{array}{c}52,6 \\
(2.378)\end{array}$ & $\begin{array}{c}46,2 \\
(2.088)\end{array}$ & $\begin{array}{c}48,1 \\
(2.174)\end{array}$ & & & & & & & & & $\begin{array}{c}44,0 \\
(1.988)\end{array}$ \\
\hline PB 260 & $\begin{array}{c}22,3 \\
(1.008)\end{array}$ & $\begin{array}{c}50,6 \\
(2.287)\end{array}$ & $\begin{array}{c}51,8 \\
(2.341)\end{array}$ & $\begin{array}{c}47,1 \\
(2.129)\end{array}$ & $\begin{array}{c}49,6 \\
(2.242)\end{array}$ & & & & & & & & & $\begin{array}{c}44,3 \\
(2.001)\end{array}$ \\
\hline
\end{tabular}

Sumber:Woelan et al., (2005, 2009); Lasminingsih et al., (2009).

Keterangan:- Sistem sadap 1/2Sd/3 (113 hari, 400 pohon) 


\section{Karakter Fisiologi Lateks}

Beberapa karakter fisiologi telah dievaluasi untuk mengetahui potensi produksi klon IRR 220 dan IRR 230 lebih awal. Karakter fisiologi yang diamati yaitu : indeks penyumbatan, kadar karet kering (KKK), lama aliran lateks (LAL), kering alur sadap (KAS) dapat dilihat pada Tabel 3 .

Perubahan sistem eksploitasi dari A (1/2 S $\mathrm{d} / 2)$ ke B (1/2 S d/3.ET 2,5\%) pada umumnya tidak menunjukkan perubahan nilai KKK secara nyata (Tabel 3). Data KKK sangat dipengaruhi oleh konsistensi perlakuan di lapangan. Nilai KKK yang relatif hampir sama pada kedua perlakuan tersebut di atas menunjukkan bahwa, kedua perlakuan tersebut memiliki intensitas eksploitasi hampir sama dalam proses regenerasi lateks in situ.

Rata-rata kadar karet masing-masing $35,4 \%$ dan $35 \%$ dan ini menunjukkan besaran nilai yang sama. Hal ini memberikan indikasi bahwa tidak terjadi perubahan pada penggunaan stimulansia. Demikian juga dengan klon PB 260 relatif hampir sama pada kedua perlakuan tersebut di atas masingmasing $34,4 \%$ dan $34,2 \%$.

Perubahan sistem eksploitasi dari A (1/2 S $\mathrm{d} / 2)$ ke B (1/2 S d/3.ET 2,5\%) pada umumnya menunjukkan perubahan nilai KKK pada klon
IRR 230 masing-masing $30,0 \%$ dan $28,0 \%$ (Tabel 3). Hasil penelitian Herlinawati dan Kuswanhadi (2012) menunjukkan bahwa penggunaan stimulansia dapat menurunkan KKK. Beberapa peneliti menyatakan, bahwa kadar karet kering erat kaitannya dengan konsekuensi sistem eksploitasi dan tersedianya waktu untuk regenerasi isi pembuluh lateks (Do et al., 1996; Siregar, 2001). Oleh karena regenerasi lateks kaitannya dengan kadar sukrosa dan fosfat organik. Penggunaan stimulan dapat menurunkan kadar sukrosa karena aktivitas metabolisme meningkat yang terlihat pada kandungan fosfat anorganik meningkat. Dalam hal ini produksi meningkat tetapi kadar karet kering menunjukkan penurunan. KKK dan produksi memiliki korelasi yang negatif (Herlinawati dan Kuswanhadi, 2012)

Karyudi et al. (2006) menyatakan bahwa klon-klon yang Slow Stater (SS), yakni klon yang memiliki tingkat metabolisme rendah sampai sedang atau yang mempunyai indeks penyumbatan tinggi menunjukkan respon baik terhadap penggunaan stimulan gas. Berdasarkan hasil penelitian tersebut, klon IRR 230 dapat dikategorikan sebagai klon yang mempunyai metabolisme sedang, indeks penyumbatan lebih tinggi dari klon pembanding PB 260.

Tabel 3. Karakterisasi fisiologi klon IRR 220 dan IRR 230 dibanding PB 260 sebagai pembanding

\begin{tabular}{lcccccc}
\hline \multirow{2}{*}{ Klon } & \multicolumn{2}{c}{ KKK $(\%)$} & \multicolumn{2}{c}{ LAL (jam) } & \multicolumn{2}{c}{ KAS (\%) } \\
\cline { 2 - 7 } & $\mathrm{A}$ & $\mathrm{B}$ & $\mathrm{A}$ & $\mathrm{B}$ & $\mathrm{A}$ & $\mathrm{B}$ \\
\hline IRR 220 & 35,4 & 35,0 & 5,25 & 5,17 & 2,50 & 9,51 \\
IRR 230 & 30,0 & 28,0 & 0,09 & 0,09 & 11,1 & 9,9 \\
PB 260 & 34,4 & 34,2 & 5,08 & 5,08 & 21,28 & 6,30 \\
\hline
\end{tabular}

Sumber: Woelan etal., $(2005,2009)$.

Keterangan : $\mathrm{A}=1 / 2 \mathrm{~S} \mathrm{~d} / 2 ; \mathrm{B}=1 / 2 \mathrm{~S}$ d/3. ET 2,5\%; KKK =Kadar Karet Kering; LAL = Lama Aliran lateks; KAS = Kering Alur Sadap 


\section{Mutu Lateks dan Sifat Karet}

Pengelompokan mutu dan sifat lateks dilakukan atas dasar hasil evaluasi Anas (1999). Hal ini dilakukan untuk mempermudah proses pengolahan agar dapat menghasilkan produk yang lebih spesifik. Mutu lateks dan sifat karet serta spesifikasi produk yang dihasilkan klon IRR 220 dan IRR 230 dibanding klon pembanding PB 260 disajikan pada Tabel 4 dan Tabel 5.

Anas (1999) menyatakan bahwa untuk memproduksi SIR 3CV dibutuhkan KKK sedang dan kandungan logam rendah dan viskositas mooney sedang. Berdasarkan atas sifat dan mutu lateks maka klon IRR 220 dapat digunakan untuk memproduksi SIR 3CV, disamping untuk SIR 3L dan lateks pekat.
Klon IRR 230 dapat digunakan untuk produksi SIR 3CV, disamping SIR 3L dan RSS.

\section{Lilit Batang}

Rata-rata perkembangan lilit batang di saat TBM dan TM klon IRR 220 dibanding dengan klon pembanding PB 260 disajikan pada Tabel 6. Perkembangan lilit batang cukup baik di saat TBM, bila dibanding dengan PB 260 pertumbuhan klon IRR 220 lebih tinggi. Laju pertambahan lilit batang di saat TBM dan TM relatif lebih tinggi dibanding dengan klon $\mathrm{PB}$ 260. Hasil analisis statistik menunjukkan bahwa, terdapat adanya perbedaan yang nyata antara ukuran lilit batang klon IRR 220 dengan klon pembanding PB 260.

Tabel 4. Mutu lateks dan sifat karet klon IRR 220 dan IRR 230

\begin{tabular}{llll}
\hline \multicolumn{1}{c}{ Karakteristik } & IRR 220 & IRR 230 & PB 260 \\
\hline - KKK (Kadar Karet Kering) & Sedang & Rendah & Sedang \\
- Vr (Viskositas mooney) & Sedang & Tinggi & Sedang \\
- PRI (Plasticity Retention Indeks) & Rendah & Sedang & Sedang \\
- Po (Nilai Plastisitas Awal) & Rendah & Sedang & Rendah \\
- Kandungan Mg dalam lateks & Rendah & Tinggi & Rendah \\
(ppm) & & & \\
\hline
\end{tabular}

Sumber: Anas etal., (1999).

Keterangan :

$\mathrm{KKK}$

PRI :

Indeks lovibond:

Rendah : $31-34 \%$

Sedang : :86-94

Rendah : :4-6

Sedang : $: 34-38 \%$

Tinggi $: \geq 95$

Sedang : :7-9

Tinggi : $38-41 \%$

Tinggi $: 10-12$

Vr:

Po

Sangat tinggi $:>12$

Rendah :55-75 Rendah : 31-40

Sedang :66-75 Sedang : 41-50

Tinggi : :76-85

Tabel 5. Spesifikasi produk yang dapat dihasilkan klon IRR 220 dan IRR 230

\begin{tabular}{lcccc}
\hline \multirow{2}{*}{ Klon } & Lateks pekat & RSS & \multicolumn{2}{c}{ SIR } \\
\cline { 3 - 5 } & & & Medium 3 CV & 3 L \\
\hline IRR 220 & S & - & S & S \\
IRR 230 & - & S & S & S \\
PB 260 & S & - & S & - \\
\hline
\end{tabular}

Sumber: Anas et al., (1999).

Keterangan: TS : Tidak Sesuai, $\mathrm{S}:$ Sesuai; RSS = Ribbed Smoked Sheets; SIR = Standard

Indonesian Rubber (SIR); CV = Constant Viscosity; L = Light; WF = Whole Field 
Tabel 6 . Perkembangan lilit batang klon IRR 220 pada TBM dan TM

\begin{tabular}{|c|c|c|c|c|c|c|c|c|c|c|c|c|c|c|}
\hline \multirow[t]{3}{*}{ Klon } & \multicolumn{12}{|c|}{ Lilit batang $(\mathrm{cm})$ pada tahun } & \multirow{2}{*}{\multicolumn{2}{|c|}{$\begin{array}{c}\text { Laju } \\
\text { Pertumbuhan } \\
(\mathrm{cm} / \mathrm{th})\end{array}$}} \\
\hline & \multicolumn{3}{|c|}{ TBM } & \multicolumn{9}{|c|}{ TM } & & \\
\hline & 2 & 3 & 4 & 5 & 6 & 7 & 8 & 9 & 10 & 11 & 12 & 13 & $\begin{array}{l}\mathrm{TB} \\
\mathrm{M}\end{array}$ & TM \\
\hline Sungei Putih & & & & & & & & & & & & & & \\
\hline IRR 220 & 19,8 & 37,4 & 47 & 53 & 57,4 & 57,9 & 60,4 & 61,5 & 63 & 64,4 & 66,1 & 68,8 & 11,1 & 2,0 \\
\hline $\begin{array}{l}\text { PB } 260 \\
\text { Sembawa }\end{array}$ & 17,2 & 32,6 & 41,8 & 47,4 & 50 & 50,7 & 54 & 54,9 & 56,6 & 56,9 & 58,1 & 58,8 & 10,1 & 1,4 \\
\hline IRR 220 & 23 & 36,1 & 46,1 & 55,7 & & & & & & & & & 10,9 & \\
\hline PB 260 & 18,4 & 28,9 & 38,2 & 47 & & & & & & & & & 9,5 & \\
\hline $\begin{array}{l}\text { Aek Paminke } \\
\text { IRR } 220\end{array}$ & 26,7 & 40,4 & 47,0 & 47,6 & & & & & & & & & 7 & \\
\hline $\begin{array}{l}\text { PB } 260 \\
\text { Aek Tarum }\end{array}$ & 24,6 & 38,3 & 45,8 & 49,4 & & & & & & & & & 8,3 & \\
\hline IRR 220 & 25,7 & 35,8 & 45,9 & & & & & & & & & & 10,5 & \\
\hline PB 260 & 27,0 & 35,1 & 44,6 & & & & & & & & & & 10,4 & \\
\hline
\end{tabular}

Sumber : Woelan (2005, 2009); Lasminingsih, et al., (2009); Aidi-Daslin (2005).

Tabel 7. Perkembangan lilit batang klon IRR 230 pada TBM dan TM

\begin{tabular}{|c|c|c|c|c|c|c|c|c|c|c|c|c|c|c|c|c|c|}
\hline \multirow[t]{3}{*}{ Klon } & \multicolumn{15}{|c|}{ Lilit batang $(\mathrm{cm})$ pada tahun } & \multirow{2}{*}{\multicolumn{2}{|c|}{$\begin{array}{c}\text { Laju } \\
\text { pertumbuhan } \\
(\mathrm{cm} / \mathrm{th})\end{array}$}} \\
\hline & \multicolumn{3}{|c|}{ TBM } & \multicolumn{12}{|c|}{ TM } & & \\
\hline & 2 & 3 & 4 & 5 & 6 & 7 & 8 & 9 & 10 & 11 & 12 & 13 & 14 & 15 & 16 & TBM & $\mathrm{TM}$ \\
\hline \multicolumn{18}{|c|}{ Sungei Putih } \\
\hline $\begin{array}{c}\text { IRR } \\
230\end{array}$ & 19,8 & 38,5 & 45,6 & 48,1 & 53,3 & 58,5 & 63,6 & 66 & 69,9 & 70,6 & 75 & 78,1 & 80 & 83,8 & 85,3 & 12,9 & 3,3 \\
\hline $\begin{array}{l}\text { PB } \\
260\end{array}$ & 19,2 & 32,9 & 47,9 & 50,1 & 59,8 & 64,4 & 69,4 & 72 & 76,8 & 78,2 & 78,2 & 79 & 82,7 & 84,2 & 86,7 & 14,4 & 3,2 \\
\hline \multicolumn{18}{|c|}{ Aek Paminke } \\
\hline $\begin{array}{l}\text { IRR } \\
230\end{array}$ & 25,8 & 41,0 & 49,5 & 51,0 & & & & & & & & & & & & 17,0 & 6,0 \\
\hline $\begin{array}{l}\text { PB } \\
260\end{array}$ & 24,6 & 38,3 & 45,8 & 49,4 & & & & & & & & & & & & 14,6 & 4,7 \\
\hline \multicolumn{18}{|c|}{ Sungei Baleh } \\
\hline $\begin{array}{l}\text { IRR } \\
230\end{array}$ & 13,4 & 32,4 & 44,3 & 52,5 & 58,9 & 62,4 & & & & & & & & & & 11,9 & 1,5 \\
\hline $\begin{array}{l}\text { PB } \\
260\end{array}$ & 11,9 & 27,3 & 41,1 & 48,9 & 54,6 & 55,3 & & & & & & & & & & 10,6 & 3,6 \\
\hline
\end{tabular}

Sumber: Woelan (2005, 2009); Aidi-Daslin(2005).

Berdasarkan hasil pengelompokan yang dibuat oleh Azwar dan Suhendry (1998), dari laju pertumbuhan per tahunnya maka klon IRR 220 termasuk kelompok pertumbuhan sedang, karena rata-rata laju pertumbuhan disaat TBM, yaitu sebesar $11 \mathrm{~cm}$ pertahun dan laju pertumbuhan disaat TM-2 yaitu $4 \mathrm{~cm}$.

Perkembangan lilit batang klon IRR 230 cukup baik disaat TBM maupun TM bila dibanding dengan PB 260 seperti yang disajikan pada Tabel 6. Berdasarkan hasil pengelompokan yang dibuat oleh Azwar dan Suhendry (1998), dari laju pertumbuhan per tahunnya maka klon IRR 230 termasuk kelompok pertumbuhan jagur, karena ratarata laju pertumbuhan di saat TBM, yaitu sebesar $14 \mathrm{~cm}$ per tahun dan laju pertumbuhan di saat TM yaitu $4 \mathrm{~cm}$. Dengan pola pertumbuhan seperti tersebut maka klon IRR 220 dan IRR 230 dapat disadap pada umur 4 tahun. Klon IRR 220 dikelompokkan ke dalam klon yang mempunyai biomassa sedang. Sedangkan klon IRR 230 di kelompokkan ke dalam klon yang mempunyai biomassa tinggi. Dari hasil evaluasi perkembangan lilit batang setiap tahunnya maka klon IRR 220 dan IRR 230 dapat disimpulkan sebagai klon penghasil latekskayu, sesuai dengan pengelompokan yang dilakukan oleh Azwar dan Suhendry (1998) dan Aidi-Daslin etal. (2009). 


\section{Tebal Kulit}

Tebal kulit merupakan kriteria yang cukup penting di dalam melakukan identifikasi suatu klon yang mempunyai keunggulan di dalam produksi lateks tinggi. Potensi produksi tinggi mempunyai korelasi yang positif dengan jumlah pembuluh lateks (Woelan et al., 2001; Woelan et al., 2013). Rata-rata tebal kulit dan anatomi kulit klon IRR 220 dan IRR 230 dibanding dengan klon pembanding disajikan pada Tabel 8 .

Kulit murni klon IRR 220 lebih tebal dari klon pembanding PB 260 maupun IRR 230. Jumlah pembuluh lateks pada kulit murni klon IRR 220 lebih banyak dibanding dengan klon pembanding dan IRR 230. Banyaknya jumlah pembuluh lateks pada klon IRR 220 memberikan suatu indikasi bahwa IRR 220 mempunyai potensi produksi lateks cukup baik. Karena jumlah pembuluh lateks merupakan salah satu komponen produksi yang berkorelasi positif dan nilainya cukup besar dengan produksi. Tebal kulit dan anatomi kulit merupakan parameter yang penting dalam melakukan seleksi klon karet unggul harapan.
Kulit murni klon IRR 220 lebih tebal dari klon pembanding PB 260 maupun IRR 230. Jumlah pembuluh lateks pada kulit murni klon IRR 220 lebih banyak dibanding dengan klon pembanding dan IRR 230. Banyaknya jumlah pembuluh lateks pada klon IRR 220 memberikan suatu indikasi bahwa IRR 220 mempunyai potensi produksi lateks cukup baik. Karena jumlah pembuluh lateks merupakan salah satu komponen produksi yang berkorelasi positif dan nilainya cukup besar dengan produksi. Tebal kulit dan anatomi kulit merupakan parameter yang penting dalam melakukan seleksi klon karet unggul harapan. Hal ini menunjukan bahwa, parameter tersebut memiliki korelasi yang cukup kuat dan nilainya positif terhadap produksi karet (Woelan dan Sayurandi, 2008; Woelan et al., 2013). Disamping itu tebal kulit juga mempunyai korelasi yang cukup kuat terhadap karakter lilit batang yaitu sebesar 0,85 (Woelan, 2013). Hasil penelitian Woelan (2013) melalui analisis regresi berganda menunjukkan bahwa tebal kulit mempunyai pengaruh positif terhadap produksi lateks. Hal ini mengindikasikan bahwa, semakin besar nilai variabel tersebut maka semakin tinggi produksi lateks.

Tabel 8. Tebal dan anatomi kulit klon IRR 220 dan IRR 230 waktu buka sadap umur 4

\begin{tabular}{cccc}
\hline \multirow{2}{*}{ Klon } & Tebal kulit $(\mathrm{mm})$ & Pembuluh lateks & $\begin{array}{c}\text { Pembuluh lateks } \\
(\mathrm{m} \mu)\end{array}$ \\
\cline { 2 - 4 } & Murni & Murni & Murni \\
\hline IRR 220 & 6,4 & 16 & 27,18 \\
IRR 230 & 5,0 & 11 & 21,90 \\
PB 260 & 5,6 & 8 & 26,56 \\
\hline
\end{tabular}

Sumber: Woelan $(2005,2009)$. 


\section{Ketahanan Penyakit}

Evaluasi terhadap ketahanan penyakit terutama ditujukan kepada penyakit daun Corynespora dan Colletotrichum. Kedua penyakit tersebut menjadi perhatian utama karena serangan penyakit dapat menyebabkan penurunan produksi sampai dengan 40\% (Pawirosoemardjo, 2000). Berdasarkan atas pengamatan penyakit di tiga lokasi rata-rata klon IRR 220 mempunyai ketahanan yang cukup baik terhadap Corynespora maupun
Colletotrichum dan demikian juga dengan klon pembanding PB 260 seperti yang disajikan pada Tabel 9. Berdasarkan hasil pengelompokan Pawirosoemardjo (2000) bahwa, klasifikasi intensitas serangan penyakit daun Corynespora dan Colletotrichum sebesar 0 20\% memasukkan klon IRR 220 dan IRR 230 ke dalam kelompok yang resisten terhadap kedua penyakit tersebut diatas, untuk ketahanan terhadap penyakit Oidium dikategorikan kurang tahan.

Tabel 9. Ketahanan penyakit daun klon IRR 220

\begin{tabular}{ccc}
\hline \multirow{2}{*}{ Klon } & \multicolumn{2}{c}{ Intensitas serangan } \\
\cline { 2 - 3 } & Corynespora & Colletotrichum \\
\hline IRR 220 & 1,33 & 10,17 \\
IRR230 & 1,33 & 9,00 \\
PB 260 & 0,00 & 16,17 \\
\hline
\end{tabular}

Sumber : Serafina et al., (2009).

\section{Karakter Batang dan Gugur Daun}

Karakterisasi batang dan gugur daun klon IRR 220 dan klon pembanding yang digunakan disajikan pada Tabel 10 . Berdasarkan perkembangan lilit batang, klon IRR 220 yang dikelompokkan sebagai penghasil lateks-kayu, maka volume kayu log yang dapat dihasilkan klon IRR 220 sebesar $0,61 \mathrm{~m}^{3}$ per pohon dan total kayu yang dapat dihasilkan $0,89 \mathrm{~m}^{3}$ per pohon pada umur 20 tahun, lebih tinggi dari klon pembanding $\mathrm{PB}$ 260. Klon IRR 230 volume kayu log yang dihasilkan sebesar $0,76 \mathrm{~m}^{3}$ dan total kayu yang dapat dihasilkan mencapai $1,17 \mathrm{~m}^{3}$ per pohon pada umur 20 tahun.

Morfologi batang klon IRR 220 lurus agak miring, bentuknya silindris, dan permukaan batangnya cukup halus, mempunyai sifat gugur daun yang serentak. Sedangkan klon PB 260, morfologi batangnya lurus tegak, silindris, permukaan batangnya cukup halus, mempunyai sifat gugur daun yang bertahap, pada klon IRR 230 morfologinya lurus tegak, bentuk batang silindris dan permukaannya cukup halus dan sifat gugur daunnya serentak. Sifat dan waktu gugur daun sangat penting diketahui karena berkaitan erat dengan pola produksi tanaman untuk menghasilkan lateks. Hasil penelitian Oktavia dan Lasminingsih (2010) menyatakan bahwa, terdapat adanya lima fase dalam perkembangan daun tanaman karet. Kelima fase yang terjadi sangat dipengaruhi oleh kondisi lingkungan terutama curah hujan dan angin. Gugur daun terjadi antara fase ketiga dan keempat, dimana energi yang dibutuhkan untuk metabolisme pembentukan lateks dialokasikan untuk pembentukan daun muda. Berdasarkan hal tersebut diatas dapat disimpulkan bahwa, terjadi adanya variasi diantara klon.

Tabel 10. Karakteristik batang dan gugur daun klon IRR 220 dan IRR 230

\begin{tabular}{clll}
\hline Klon & \multicolumn{1}{c}{ Morfologi batang } & $\begin{array}{c}\text { Sifat gugur } \\
\text { daun }\end{array}$ & $\begin{array}{c}\text { Waktu gugur daun } \\
\text { (bulan) }\end{array}$ \\
\hline IRR 220 & Agak miring, silindris, halus & Serentak & Februari - Maret \\
IRR 230 & Tegak lurus, silindris, halus & Serentak & Februari - Maret \\
PB 260 & Lurus, silindris, halus & Bertahap & Februari - Maret \\
\hline Sumber: Woelan etal., (2005). & &
\end{tabular}




\section{Adaptasi}

Pengujian adaptabilitas dan stabilitas klon dilakukan untuk mengetahui adanya kesesuaian lingkungan tumbuh suatu klon. Oleh karena adanya interaksi genotipe $\mathrm{x}$ lingkungan. Faktor lingkungan memiliki peranan dalam penampilan fenotipe tanaman (Syukur et al., 2012). Pengujian bersifat uji pengembangan dengan luas plot 1 ha (1 ancak sadap) per klon di dua lokasi yaitu daerah curah hujan $(\geq 3500 \mathrm{~mm} /$ th dan yang mempunyai bulan kering panjang (3-4 bulan). Stabilitas suatu genotipe adalah kemampuan genotipe untuk hidup pada berbagai lingkungan yang seragam sehingga fenotipenya tidak banyak mengalami perubahan pada tiap-tiap lingkungan tersebut (Syukur et al., 2015). Hasil analisis yang telah dilakukan memperlihatkan adanya perbedaan pertumbuhan dan produksi dari klon IRR 220 dengan klon pembanding PB 260 pada lokasi yang digunakan yang dapat dilihat pada Tabel 11 dan Tabel 12. Perbedaan tersebut kemungkinan disebabkan oleh adanya interaksi antara genotipe dan lingkungan tumbuh.

Perhitungan indeks stabilitas berdasarkan metode Francis dan Kenneberg (1978) dapat diterangkan dengan menggunakan nilai kuadrat tengah $\left(\mathrm{Si}^{2}\right)$ atau ragam dan koefisien keragaman $\left(\mathrm{KK}_{\mathrm{i}}\right)$ yang disajikan pada Tabel 11 dan Tabel 12. Klon IRR 220 dikelompokkan ke dalam klon yang mempunyai pertumbuhan cukup stabil karena nilai $\mathrm{S}_{\mathrm{i}}{ }^{2}$ dan $\mathrm{KK}_{\mathrm{i}}$ kecil yaitu masing-masing 0,34 dan $1,25 \%$. Demikian juga produksi yang dihasilkan dari beberapa lokasi yang diamati menunjukkan adanya kestabilan dari klon IRR 220, yaitu dengan nilai ragam $\left(\mathrm{Si}^{2}\right)=1,3$ dan $\mathrm{KK}=2,07 \%$. Kecenderungannya klon IRR 220 tumbuh baik dan potensi produksinya juga tinggi pada daerah curah hujan sedang sampai daerah kering.

Tabel 11. Data pertumbuhan TBM, nilai ragam $\left(\mathrm{S}_{\mathrm{i}}^{2}\right)$ dan Koefisien Keragaman (KK) klon IRR 220

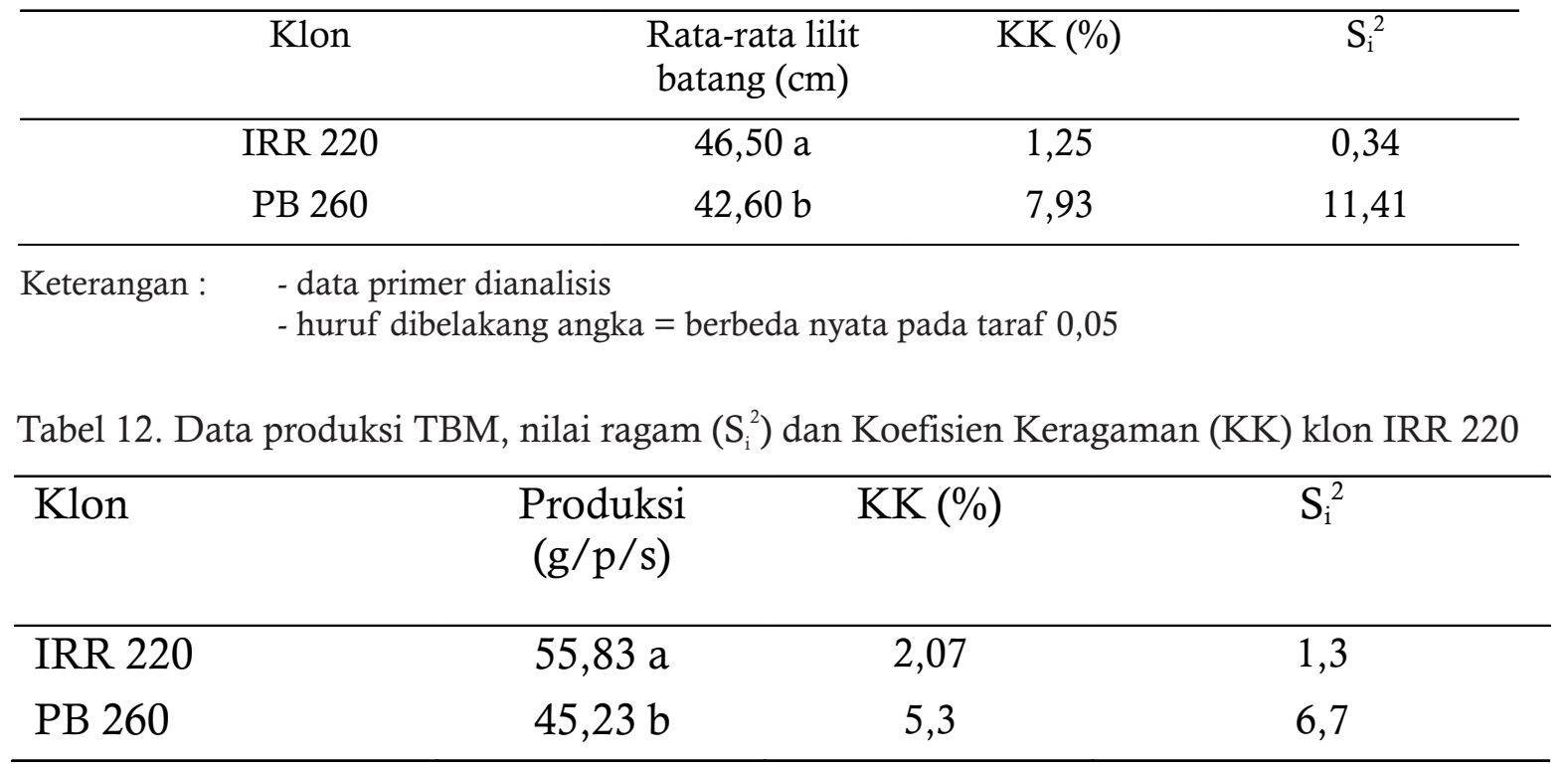

Keterangan:

- data primer dianalisis

- huruf dibelakang angka = berbeda nyata pada taraf 0,05 
Perhitungan indeks stabilitas untuk klon IRR 230 berdasarkan metode Francis dan Kenneberg (1978) dapat diterangkan dengan menggunakan nilai ragam $\left(\mathrm{Si}^{2}\right)$ dan koefisien keragaman $\left(\mathrm{KK}_{\mathrm{i}}\right)$ yang disajikan pada Tabel 13 dan Tabel 14. Klon IRR 230 dikelompokkan ke dalam klon yang mempunyai pertumbuhan cukup stabil karena nilai $\mathrm{S}_{\mathrm{i}}^{2}$ dan KK kecil yaitu masing-masing 4,88 dan $4,76 \%$. Demikian juga produksi yang dihasilkan dari beberapa lokasi yang diamati menunjukkan adanya kestabilan dari klon IRR
230, yaitu dengan nilai ragam $\left(\mathrm{Si}^{2}\right)=0,66$ dan $\mathrm{KK}=1,79 \%$. Kecenderungannya klon IRR 230 tumbuh baik dan potensi produksinya juga tinggi pada daerah curah hujan sedang sampai daerah kering.

Berdasarkan daya adaptabilitas dan stabilitas pertumbuhan dan produksi dari klon IRR 220 dan IRR 230 yang cukup baik, maka klon IRR 220 dan IRR 230 dapat dikategorikan sebagai klon penghasil lateks maupun kayu.

Tabel 13. Data pertumbuhan TBM, nilai ragam $\left(\mathrm{S}_{\mathrm{i}}^{2}\right)$ dan Koefisien Keragaman (KK) klon IRR 230

\begin{tabular}{cclc}
\hline Klon & $\begin{array}{c}\text { Rata-rata lilit } \\
\text { batang }(\mathrm{cm})\end{array}$ & $\mathrm{KK}(\%)$ & $\mathrm{S}_{\mathrm{i}}{ }^{2}$ \\
\hline IRR 230 & $46,47 \mathrm{a}$ & 4,76 & 4,88 \\
PB 260 & $41,93 \mathrm{~b}$ & 7,93 & 11,41 \\
\hline
\end{tabular}

Keterangan:

- data primer dianalisis,

- huruf dibelakang angka = berbeda nyata pada taraf 0,05

Tabel 14. Data produksi TBM, nilai ragam $\left(\mathrm{S}_{\mathrm{i}}^{2}\right)$ dan Koefisien Keragaman (KK) klon IRR 230

\begin{tabular}{cccc}
\hline ddKlon & Produksi $(\mathrm{g} / \mathrm{p} / \mathrm{s})$ & $\mathrm{KK}(\%)$ & $\mathrm{S}_{\mathrm{i}}{ }^{2}$ \\
\hline & & & \\
IRR 230 & $45,20 \mathrm{a}$ & 1,79 & 0,66 \\
PB 260 & $45,23 \mathrm{a}$ & 5,3 & 6,7 \\
\hline
\end{tabular}

Keterangan : huruf dibelakang angka $=$ berbeda nyata pada taraf 0,05 
Tabel 15. Karakteristik klon IRR 220 dan IRR 230 dibanding PB 260

\begin{tabular}{llll}
\hline \multicolumn{1}{c}{ Karakterisasi } & IRR220 & IRR 230 & PB 260 \\
\hline Produksi & 5 & 4 & 5 \\
- Produksiawal & 5 & 5 & 4 \\
- Produksilanjutan & 2 & 3 & 3 \\
- Respon terhadap stimulan & 4 & 4 & 3 \\
- Respon terhadap kekeringan & & \\
$\quad$ kulit & & & \\
& & & \\
Pertumbuhan & 3 & 5 & 4 \\
- Pertumbuhan saat buka sadap & 3 & 4 & 3 \\
- Pertumbuhan selama sadap & 4 & 4 & 3 \\
- Tebal kulit murni & 4 & 4 & \\
- Ketahananterhadap pelukaan & & & \\
& & & \\
Ketahanan penyakit & 2 & 5 & 3 \\
- Angin & 4 & 5 & 5 \\
- Jamur Upas & 5 & 5 & 4 \\
- Oidium & 4 & 3 & 4 \\
- Colletotrichum & 5 & 3 & 4 \\
- Corynespora & 5 & 5 & 5 \\
- Jamur upas & & & \\
\hline
\end{tabular}

Sumber: Aidi-Daslin et al., (2009).

Keterangan:

-Sangatbaik : $: 5 \quad$-Sedang $: 3$

-Kurang $\quad: 2 \quad$-Baik $\quad: 4$

- Jelek $\quad: 1$

\section{Rangkuman Keunggulan}

Klon IRR 220 dan IRR 230 sebagai klon anjuran komersial penghasil lateks-kayu. Rangkuman keunggulan IRR 220 dan IRR 230 yang telah dimiliki dibanding klon PB 260 disajikan pada Tabel 15.

\section{Kesimpulan}

Klon IRR 220 dan IRR 230 merupakan klon penghasil lateks-kayu, dapat disadap pada umur 4 tahun, produksi awal cukup baik. Produksi kumulatif 5 tahun pertama adalah $10.511 \mathrm{~kg} / \mathrm{ha}$ dan rata-rata $\geq 2191 \mathrm{~kg} / \mathrm{ha} /$ th (IRR 220) dan $9080 \mathrm{~kg} / \mathrm{ha} /$ th dan rata-rata $\geq$
$2095 \mathrm{~kg} / \mathrm{ha} /$ th (IRR 230), ketahanan terhadap KAS (Kering Alur Sadap) cukup baik dan juga terhadap penyakit daun Corynespora dan Colletotrichum cukup baik. Tumbuh cukup baik pada daerah basah sampai dengan daerah kering. Klon IRR 220 dan IRR 230 merupakan klon penghasil lateks-kayu.

\section{Daftar Pustaka}

Aidi- Daslin., Azwar, R., dan Ginting, S. (1995). Keragaan beberapa klon karet introduksi di kebun pengujian dan tanaman komersial. Prosiding Lokakarya Nasional Pemuliaan Tanaman Karet. Medan, Nopember 1995. 
Aidi-Daslin. (2005). Kemajuan pemuliaan dan seleksi dalam menghasilkan kultivar karet unggul. Prosiding Lokakarya Nasional Pemuliaan Tanaman Karet. Medan, Nopember 2005.

Aidi-Daslin. (2009). Pengujian lanjutan potensi keunggulan klon karet harapan IRR seri 100. Laporan Hasil Penelitian. Medan. Balai Penelitian Sungei Putih.

Aidi-Daslin. (2009). Bahan tanaman klon karet unggul. Medan : Balai Penelitian Sungei Putih.

Anas, A., Manurung, M., Azwar, R., dan Woelan, S. (1999). Karakterisasi mutu lateks dan sifat karet klon harapan. Laporan Hasil Penelitian. Medan. Balai Penelitian Sungei Putih.

Azwar, R. and Aidi-Daslin. (1993). Performance of 1974 multilatera exchange clones at various location in Indonesia. Indonesian Journal of Crop Science, 8(1), 11 22.

Azwar R., Woelan, S., Aidi-Daslin, dan Suhendry, I. (1998). Klon harapan seri IRR (Promising IRR series clones). Prosiding Lokakarya Nasional Pemuliaan Karet dan Diskusi Nasional Prospek Karet Alam Abad 21. Medan, Desember 1998.

Azwar, R. dan Suhendry, I. (1998). Kemajuan pemuliaan karet dan dampaknya terhadap pada peningkatan produktivitas. Pros. Lok. Nasional Pemuliaan Karet dan Diskusi Nasional Prospek Karet Alam Abad 21. Medan, Desember 1998.

Chin, P. S. and Khoo, T. C. (1977). Rubber wood an under exploited Resource. PLRS. Bulletin Rubber Research Institute of Malaysia, 49, 54-60.

Do, K. T. and Ngia, A.N. (1996). Effects of tapping and intensive stimulation on yield, dryness incidence, and some physiological latex parameter of clone RRIM 600. Journal Natural Rubber Research, 11(3), 18-25.

Francis, T. R. and Kenneberg, L. W. (1978). Yield stability studies in short-season maize. 1. A descriptive method for grouping genotipys. Canadian Journal of Plant Science, 58, 1029-1034.
Herlinawati, E. dan Kuswanhadi. (2012). Pengaruh penggunaan stimulan gas terhadap produksi dan karakter fisiologi klon BPM 24. Jurnal Penelitian Karet, 30(2), 86-99.

Karyudi., Sumarmadji., dan Bukit, E. (2006). Penggunaan stimulan gas etilen untuk meningkatkan produktivitas tanaman karet. Prosiding Lokakarya Nasional Budidaya Tanaman Karet. Medan, September 2006.

Oktavia, F. dan Lasminingsih, M. (2010). Pengaruh kondisi daun tanaman karet terhadap keragaman hasil sadap beberapa klon seri IRR. Jurnal Penelitian Karet, 28(2), $32-40$.

Pawirosoemardjo, S., Sujatno, dan Suwarto. (2000). Studi perkembangan ras patogen dan reistensi klon anjuran generasi IV dalam rangka pengendalian penyakit gugur daun Corynespora dan Colletotrichum. Laporan Tengah Tahun PAATP. Medan. Pusat Penelitian Karet.

Permadi, G. (2010, Desember). Kayu karet untuk industri: Terbuka lebar. Hevea, 2(2) ,18-20.

Serafina, R., Suyatno, dan Pawirosoemardjo, S. (2005). Resistensi klon karet harapan terhadap penyakit gugur daun Corynespora dan Colletotrichum. Prosiding Lokakarya Nasional Pemuliaan Tanaman Karet. Medan, Nopember 2005.

Siregar, T. H. S. (2001). Tanggap produksi dan karakter fisiologi lateks terhadap sistem eksploitasi pada beberapa klon karet IRR seri 100. Magister. Tesis, Institut Pertanian Bogor, Bogor.

Syukur, M., Sujiprihati, S., dan Yunianti, R. (2015). Teknik pemuliaan tanaman. Jakarta : Penebar Swadaya.

Woelan, S. dan Azwar, R. (1992). Kemajuan persilangan dan seleksi tanaman karet Hevea brasiliensis Muell. Arg. (The development of artificial cossing and selection in Hevea brasiliensis Muell. Arg). Prosiding Lokakarya Nasional Pemuliaan Tanaman Karet. Medan, Desember 1992. 
Woelan, S., Aidi-Daslin, Azwar, R., dan Suhendry, I. (2001). Keragaan klon karet unggul harapan IRR seri 100. Prosiding Lokakarya Nasional Pemuliaan Karet. Pusat Penelitian Karet. Sembawa, Nopember 2001.

Woelan, S., Aidi-Daslin., Suhendry, I., dan Lasminingsih, M. (2005). Evaluasi keragaan klon karet IRR seri 100 dan 200. Prosiding Lokakarya Nasional Pemuliaan Tanaman Karet. Medan, Nopember 2005.

Woelan, S., Aidi-Daslin., dan Suhendry, I. (2006). Potensi keunggulan klon karet generasi-IV seri IRR. Prosiding Lokakarya Nasional Budidaya Tanaman Karet. Medan, September 2006.
Woelan, S. dan Sayurandi. (2008). Analisis sidik lintas komponen hasil lateks-kayu dan seleksi genotipe hasil persilangan di pengujian tanaman semaian. Jurnal Penelitian Karet, 26(2), 98-113.

Woelan, S., Aidi-Daslin, Lasminingsih, M., dan Suhendry, I. (2009). Evaluasi Keragaan Klon Karet IRR seri 200 dan 300 pada tahap pengujian. Prosiding Lokakarya Nasional Pemuliaan Tanaman Karet. Batam, Agustus 2009.

Woelan, S., Sayurandi, dan Pasaribu, S. A. (2013). Karakter fisiologi, anatomi, pertumbuhan dan hasil lateks klon IRR seri 300. Jurnal Penelitian Karet, 31(1), 1 - 12. 
Keunggulan klon karet IRR 220 dan IRR 230

\section{Lampiran 1}

\begin{tabular}{|c|c|c|}
\hline \multicolumn{3}{|c|}{ DESKIRIPSA KARET KLON IRR 220} \\
\hline $\begin{array}{l}\text { Tipe varietas } \\
\text { Anel/silailah }\end{array}$ & $\vdots$ & Klon (perbanyakan vegetatif) \\
\hline \multicolumn{3}{|r|}{ 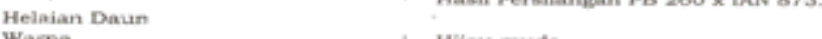 } \\
\hline Wama & $=$ & Hijau muda. \\
\hline Kilazuan & 1 & Kusam. \\
\hline Tekstur & : & Halus. \\
\hline Kelcakuan & ; & Agak kaku. \\
\hline Bentuk & 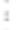 & $\begin{array}{l}\text { Elips. } \\
\text { Elat. }\end{array}$ \\
\hline Pinzajir daun & ; & Rata. \\
\hline Penampang memanjang & $i$ & Lurus. \\
\hline Penampang melintang & 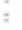 & Agak cekung. \\
\hline Posiei helaien daun & i & Terpisah. \\
\hline Simetris daun pingugir & $=$ & simetris. \\
\hline Ukuran daun & & $2,6: 1$. \\
\hline Ujung daun & 3 & Sedang. \\
\hline \multicolumn{3}{|l|}{ Tangkai Daun } \\
\hline $\begin{array}{l}\text { Powini } \\
\text { Rentuk }\end{array}$ & : & Mendatar. \\
\hline $\begin{array}{l}\text { Dentuk } \\
\text { Panjintig }\end{array}$ & ; & $\begin{array}{l}\text { Lurus. } \\
\text { Sedang. }\end{array}$ \\
\hline Ukuran kakd & $i$ & Sedang. \\
\hline Bentuk kaki & $i$ & Agak kecil. \\
\hline \multicolumn{3}{|l|}{ Anak Tangkai Daun } \\
\hline Poolsi & $:$ & Lturus. \\
\hline Dentuk & : & Lurus. \\
\hline Panjang & : & Sedang. \\
\hline Sudut & ; & Sedang. \\
\hline \multicolumn{3}{|l|}{ Payung Daun } \\
\hline Bentuk & 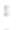 & Setengah lingkaran. \\
\hline Besar & & Agak besar. \\
\hline Kerapatan permukaan & ; & Terbuka. \\
\hline Jarak antar payung & $i$ & Sedang. \\
\hline Meta & $:$ & \\
\hline Letak mata & ; & Rata. \\
\hline $\begin{array}{l}\text { Bekas tanglcai daun } \\
\text { Kutit batang }\end{array}$ & 1 & Menonjol. \\
\hline \multicolumn{3}{|l|}{$\begin{array}{l}\text { Kudit batang } \\
\text { Corak kolit gabus }\end{array}$} \\
\hline Warna kulit gabuin & $i$ & Coktat muda. \\
\hline \multicolumn{3}{|l|}{ Biji } \\
\hline $\begin{array}{l}\text { Bentuk } \\
\text { Ukuran }\end{array}$ & & Lonjong. \\
\hline \multirow{2}{*}{\multicolumn{3}{|c|}{$\begin{array}{l}\text { Ukuran } \\
\text { Protuksi Karet Kering } \\
\text { Kuraulatif } 5 \text { tahun (kg/ha) }\end{array}$}} \\
\hline & & 10.511. \\
\hline Kumulatif 10 tahun $(\mathrm{kg} / \mathrm{ha})$ & : & 20.086 \\
\hline $\begin{array}{l}\text { Kumulatif } 15 \text { tahum }(\mathrm{kg} / \mathrm{ha}) \\
\text { Rata-rata (kge/ha/trohn) }\end{array}$ & 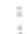 & 32.865 \\
\hline Rata-rata (kg/ha/tahun) & & \\
\hline
\end{tabular}

Pertumbuhan

Llit batang TaM $(4 \mathrm{th})(\mathrm{cm})$ Tebal kulit murni (em)

Potensi Kayu (umur 20 tahun) Volume kays batang bebas cabang : 0,61 . ( $\mathrm{m}^{2} /$ pohon)

Volume kayu kanopi (m3/pohon) : : 0.28 Volume kaysa total (m²/pohon) ; 0,89 .

Sifat Selounder

Respon terhadap stimulas Ketihanan terhadap angin Ketahanan terhadap KAS Resistensi terhadap ods Resistensil terhadap oidusm Resistensil temadap Coblotrichum Resistensi terhadap Corynespora

\section{Kurang}

Kurang Sedang

Sangat resisten.

Resisten.

Sangat resisten.

Lateks

Warna

KKX (Kadar Karet Kering

Sangat resisten.

Vr (Viskasitas Retertion Indeks)
PRu (Plasticity Retention Indekes)

Po (Nitail Plastisitas Awal)

Putih.

$30-37$

50-70

$70-85$

$24-40$

1100 .

Per.eliti

Sekar Woelan, Rasidin Nzwaz, AidiDaslin Sagala, Mudji Lasminingsih, Aini Pasaribu.

Pemilik Varietas

Pusat Penelitian Karet.

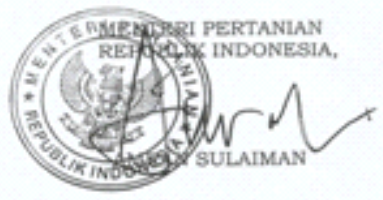



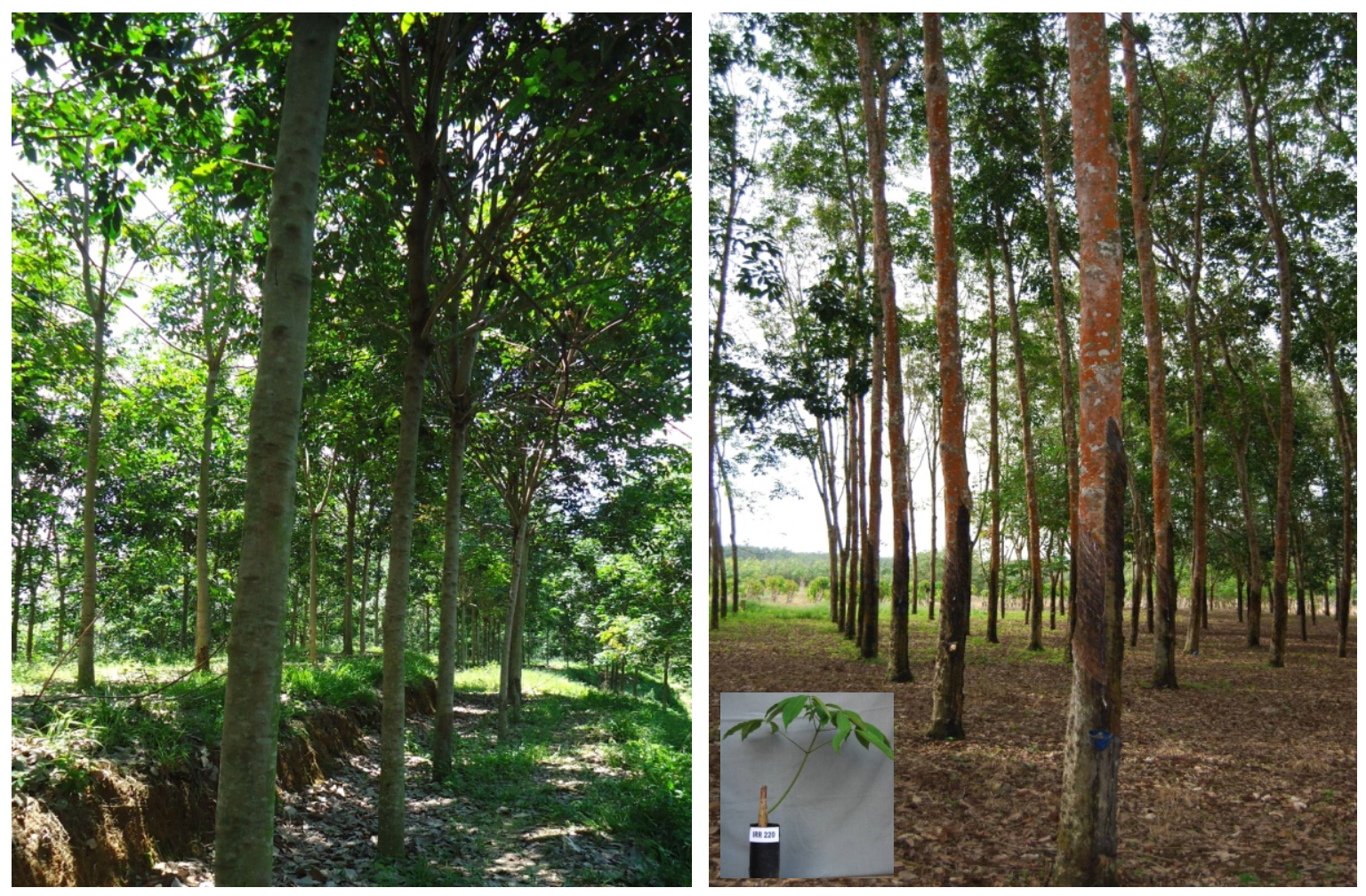

Penampilan tanaman polybeg, TBM, dan TM klon IRR 220 
Keunggulan klon karet IRR 220 dan IRR 230

\section{Lampiran 3}

KEPUTUSAN MENTERI PERTANIAN REPUBLIK INDONESIA TANGGAL : 26 Jaknarl 2016

DESKRIPSI KARET KLON IRR 230

Tipe varietas

Helainn Daun

Helaian Daun

Warna

Kilatain
Tekstur

Kekaksuan

Bentuk

Pingegir daun

Penampang memanjang

Penampang melintan

Pimetris daun ping

Uimetris daun ping

Ukuran daun

Tangkai Daun

Positai

Bentuk

Ukuran kak

Bentuk kaki

Annk Tangkeai Daun

Prosisi

Bentuk

Panjang
Sucut

Payung Daun

Bentuk

Kerapatan perrnukaan

Jarak antar payung

Mata

Letak mata

Bekas tangkai daun

Kuilit batang

Corak kulit gabus
Warna kulit gabus

Berntuk

Ukuran

Produksal Karet Kerin

Kurmulatif 5 tahun $(\mathrm{kg} / \mathrm{ha}$ Scate-rata (kg/ha/tahun)
Klon (pebanyakan vegetatif

Has pernilangan K100 BPM 101 x FX 2784 .

Hjau kekuningar.
Tidak mengkilat.

Halus.

Agak keaku.

Elips.

Rata.

Rata.

Terpisah.

Simetris.

Sedang.

Mendatar

Agak panjang.

Sedare

Agak berlekuk.

Ke bawah.

Lurus.

Pedang (s 60 ).

Kerucut terpotong

Sedang.

Terbuka.

Rata.

Nlur lebar tidak teratur

Coklat.

Bulat pipih.

Sedang

9.080.

17.370

3:.442

Pertumbuhan

Lilit batang TBM (4 th) $(\mathrm{cm}) \quad: 45,6$

Pertambahan lilts batang TM (cm) : 3.9 .

Tehal kulit mumi (em)

5,9 .

Potensi Kayu fumur 20 tahur

Volume kayu batang bebas cabang : 0,76 .

(m3/pohon)

Volume kayu kanopi (m³ $\mathrm{m}^{3} /$ pohon) $\quad: 0,41$.

Volume kayu total (m²/pohon) $\quad ; 1,17$

Situt Sekunder

Respen terhadap stimulas

Ketahanaz terhadap angin

Keriahanan terhadap KAS

Resistensil terhadap Odtum

Resistensi terhadap Colletotrichiom

Resit tensi terhadap Corynespana

Resistensi terthadap Jamuir Upas

Lateks

KKK RKader Karet Kering

Vit (1) kositas Retention Indekt

PRi (Plasticity Retention Indeks)

Po ONilai Plastisitas Awalf

Kandungan Mg dalam lateks

Sodang.

Bailc.

Baik.

Sangat resisten.

Moderat.

Sangat resisten.

Putih.

$76-85$

$86-8$.

$41-50$.

1.200

Peneliti

Sekar Woelan, Rasidin Azwar, NidiDaslin Sagala, Mudji Laseminingsih, Subendry. Smyurandi, Syarifa Aini Pasaribu.

Pemilik Varieta:

: Pusat Penelitian Karet. 
Warta Perkaretan 2016, 35 (2), 89-106

Lampiran 4
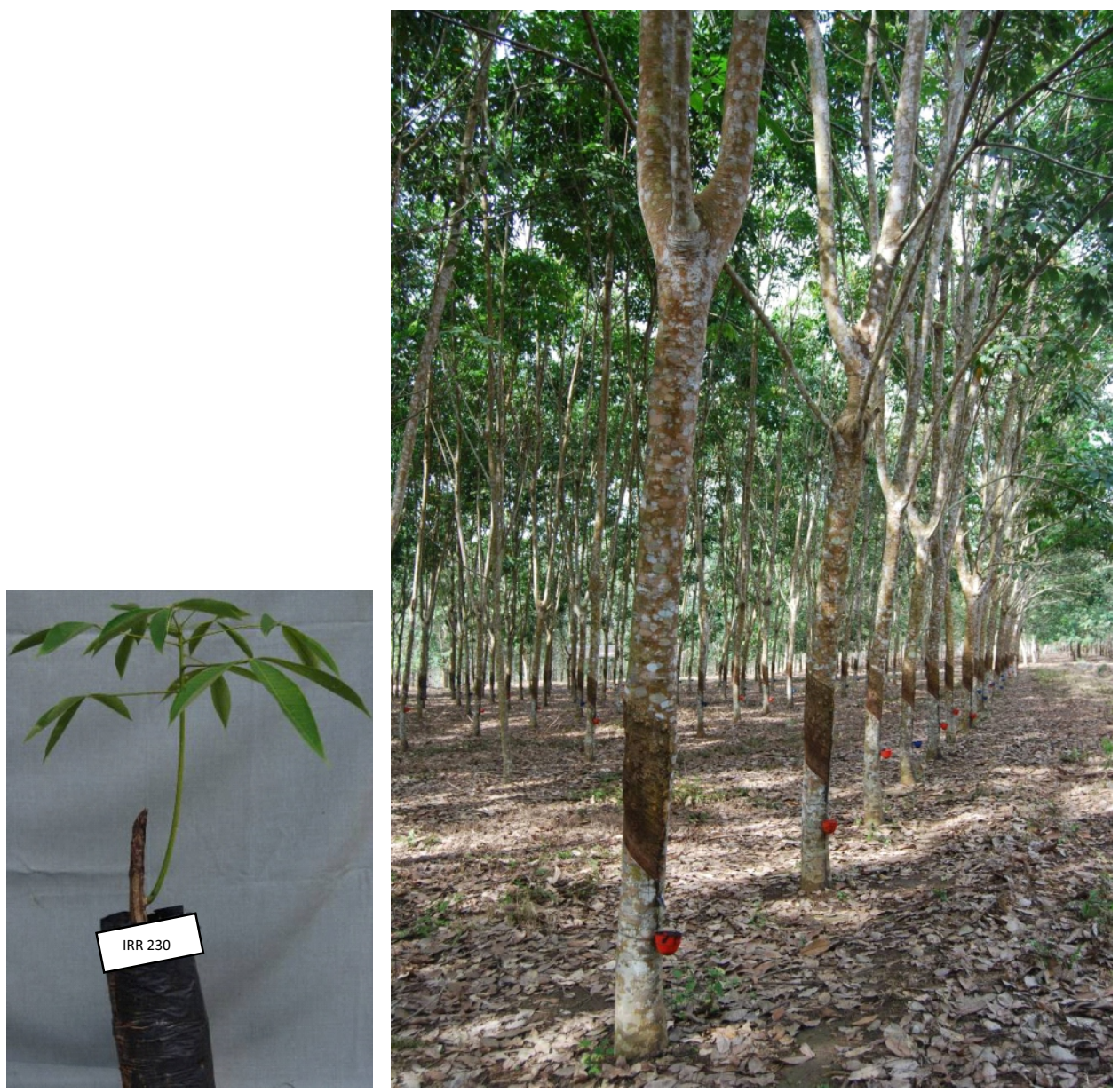

Penampilan tanaman polibeg dan TM klon IRR 230 